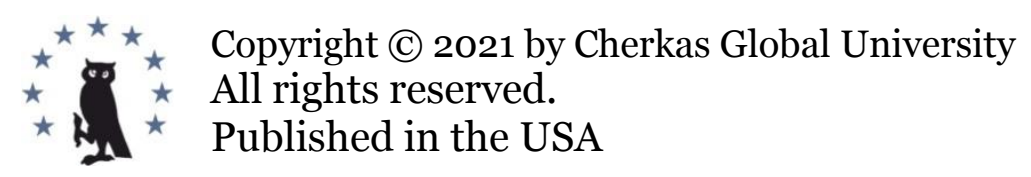

European Journal of Contemporary Education

E-ISSN 2305-6746

2021. 10(4): 943-957

DOI: 10.13187/ejced.2021.4.943

https://ejce.cherkasgu.press

IMPORTANT NOTICE! Any copying, reproduction, distribution, republication (in whole or in part), or otherwise commercial use of this work in violation of the author(s) rights will be prosecuted in accordance with international law. The use of hyperlinks to the work will not be considered copyright infringement.

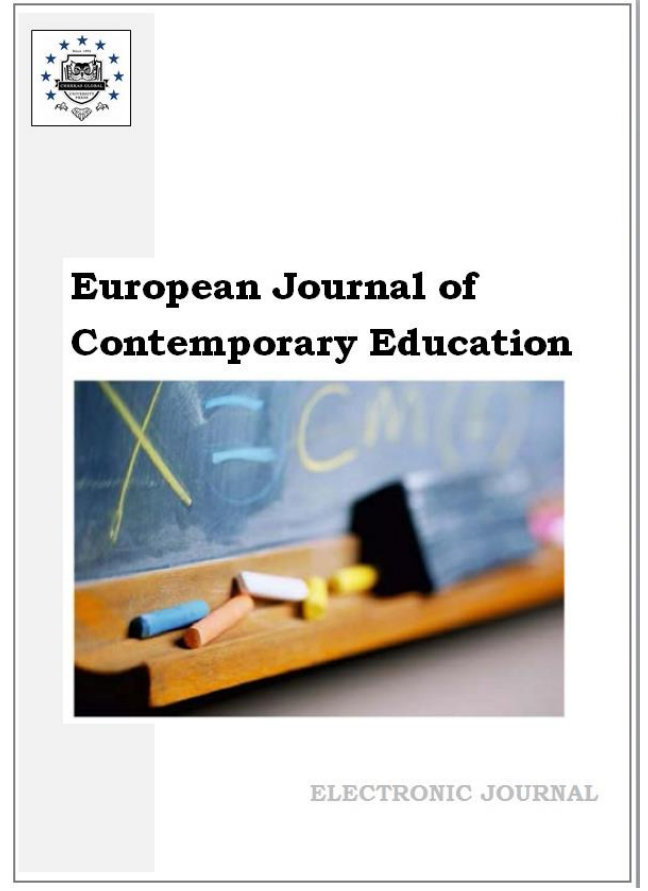

\title{
Formation of Universal Competencies of Undergraduates during Development of the Plot of Web-Quest
}

Natalya I. Isupova a ${ }^{a}$, , Ekaterina A. Mamaeva a, Tatyana V. Masharova ${ }^{b}$, Maria N. Tsygankova ${ }^{c}$

a Vyatka State University, Kirov, Russian Federation

b Moscow City Pedagogical University, Moscow, Russian Federation

${ }^{c}$ Russian National Research Medical University named after N.I. Pirogov, Moscow, Russian Federation

\begin{abstract}
The paper tackles the issue of using the educational web-quest technology in forming universal competencies of students of higher educational establishments.

The aim of the paper is to offer a theoretical grounding and to experimentally test the efficiency of forming the theory of web-quest which helps to form students' universal competencies and improve the quality of higher education on the whole.

The methodology involves the analysis of works devoted to issues and the prospects of educational informational support, stating the potential of web-quest technology for forming the necessary competencies and personal qualities. For the experimental assessment, empirical methods were used (observation, analysis of the content of web-quests, results from completing tasks, and the role of this approach in forming universal competencies).

Research results. The authors specify the structure-forming and meaningful role of the story line as an element of a web-quest, the prospect of its creating to increase the quality of teaching undergraduates, its advantages and disadvantages in forming the needed competencies and personal qualities of future specialists (training program 44.04.01 Pedagogical education, profile Informatization of education (master's degree).

The conclusion proves that working over forming a web-quest story line contributes to forming the students' universal competencies and necessary personal qualities, as well as to improving the quality of teaching on the whole.

\footnotetext{
${ }^{*}$ Corresponding author

E-mail addresses: natalyisupova@mail.ru (N.I. Isupova), mamaevakathy@gmail.com (E.A. Mamaeva), mtv203@mail.ru (T.V.Masharova), m9055095445@yandex.ru (M.N. Tsygankova)
} 
Keywords: digital technologies, basic personal traits, game space, elements of story, personal fulfillment.

\section{Introduction}

\subsection{The relevance of the problem}

Forming universal competencies (critical thinking, project work, cross-cultural interaction, communication, collaboration, etc.) serves as the basis of many international practices (Frumin et al., 2018). Federal state educational standards in Russia are oriented towards upgrading the content of training programs, introducing technical innovations, and helping teachers develop their knowledge of digital technologies, including web apps, mobile services, data analysis systems (Serditova, Belotserkovsky, 2020).

New demands from both state and society of the education system make it necessary to establish and apply effective methods of assessing students' basic personal abilities and soft skills (such as communication, teamwork on a project, emotional stability, etc.) (Soboleva, 2019).

V. Grinshkun et al. demonstrated that these competencies are much more valued by potential employers than knowledge of theory and professional skills (Grinshkun et al., 2019). A web-quest boosts cognitive activity; supports teamwork on a set of educational tasks; and activates intuition, leadership, attention, etc. (Hill, Knutzen, 2017). A. Lagunov and N. Podorojnyak showed that a web-quest, as an educational application of technology, is an effective way to put in practice the ideas of system-activity and competence approaches in education (Lagunov, Podorojnyak, 2017).

Besides, several extra conditions for forming the needed personal qualities appear if the participants of the teaching-learning process interact at the stages of projecting and web-quest (Nemtinov et al., 2020). Still, logical sequence of events in a web-quest causes some methodical issues for teachers, such as a lack of experience in creative work of such a kind, underestimating the plot, a low level of system thinking, time expenditures, difficulties in correlating the course content with the game space of a web-quest and the universal competencies formed (Soboleva, 2019).

While F. Zafar, J. Wong, M. Khalil described the details of how to prepare for creating educational web-quests (Zafar et al., 2018), still certain issues remain unresolved. They are the relationship between the universal competencies formed, the teaching results planned and the possibilities of the game space; preparation of the plot which suits the educational purposes, contemporary challenges, and needs of the students as much as possible, projecting educational game space, filling it with interactive elements suiting the mechanics of web-quests, measuring the result of forming universal competencies (Shulgina et al., 2018).

The hypothesis of the research is to describe story lines, interaction of characters, game mechanisms; it should contribute to forming the needed universal competencies of undergraduates. Special attention is to be paid to work with the story line of a web-quest.

\subsection{The aim of the research}

The aim of the research is determined by the necessity to use didactic abilities of a web-quest for improving the quality of higher school education, for effective forming the needed universal competencies in students.

The tasks of the research:

- to analyze the experience of using a web-quest technology for the sake of forming universal competencies of master's students, as well as the needed personal qualities, and improving the quality of teaching on the whole;

- to specify the concept "story line" as a system-making element of a web-quest and as a requirement to the level of universal competencies of undergraduates;

- to research the specific features of projecting player space of an educational web-quest by means of modern digital technologies;

- to formulate and put in practice the stages of working out the story line of a web-quest by the example of a certain software tool;

- to describe procedures and principles of measuring universal skills of master's students as for their work with the content of a web-quest;

- to prove experimentally that the offered teaching-learning activity is effective in forming the needed universal competencies of master's students. 


\section{Relevance}

\subsection{Literature review}

\subsubsection{Russian literature review}

The technology of an educational web-test as the basis for development and self-actualization of future higher school leavers, for their being in demand in the profession, their social inclusion and active civic consciousness is a topical sphere of development in the didactic system (Koreshnikova et al., 2020).

I.D. Frumin, M.S. Dobryakova, K.A. Barannikov and I.D. Remorenko suppose that the idea of universal competencies is grounded in the American tradition of differentiating professional skills into soft skills and hard skills (Frumin et al., 2018). For a long time it was considered that hard skills should dominate in the structure and the system of professional higher education was oriented at forming hard skills. V. Grinshkun, E. Bidaibekov, S. Koneva, and G. Baidrakhmanova think that nowadays the other point of view prevails; many researchers consider that professional success is mostly dependable on soft skills, a set of special personal qualities (Grinshkun et al., 2019). As for higher schools in Russia, most educational institutions are still oriented on the priority of professional competencies formation (Astashova et al., 2018).

According to N.E. Serditova and A.V. Belotserkovsky, despite the obvious overprofessional nature of universal competencies, the basis for their formation is the solution of practice-oriented tasks (Serditova, Belotserkovsky, 2020). Universal competencies are embedded in Federal state educational standards as planned educational results in Bachelor's and Master's programs (Nemtinov et al., 2020).

Many Russian research papers are devoted to universal competencies as an educational result and description of didactic technologies for their formation and the choice of evaluation tools to prove whether the needed result has been achieved (Kuzminov et al., 2019). A. Krupkin and M. Sinyakova experimentally prove that universal competencies are an important element of the result of higher education (Krupkin, Sinyakova, 2020).

The issue of special educational conditions which could provide efficiency of forming professional competencies and personal qualities of future specialists is very topical in different spheres (Ivanova, 2018). Requirements of professional employers to future specialists are analyzed (Frumin et al., 2018), the researchers conclude that stating the level of universal competencies includes such elements as observing students' behavior during their problem-solving activity, an open dialogue in online communication, psychological tests and cases, business games.

V.V. Belkina and T.V. Makeeva state that the success of the formation of universal competencies is undoubtedly influenced by motives or situations of choosing a future profession by a young person (Belkina, Makeeva, 2018).

I.D. Frumin, M.S. Dobryakova, K.A. Barannikov and I.D. Remorenko try to answer the following questions: which elements (knowledge, skills, attitudes, and values) are included in universal competencies; if there is any need in special courses of developing universal competencies, if they can be formed just at studying the subjects included in the curriculum, which practices could be used to form and assess them, if digital and innovative educational technologies can contribute to developing the universal competencies (Frumin et al., 2018).

N.I. Isupova and T.N. Suvorova name such pedagogical approaches which are proved to contribute to forming universal competencies as using cognitive maps, scenario tasks on the subject, interactivity, problem-based learning, learning through research, test labyrinths, stimulators, game web-services (Isupova, Suvorova, 2018).

M.N. Popova and I.P. Popov consider that a web-quest technology is an effective and promising way of using digital and innovational educational technologies in conditions of modern practice-oriented higher school education (Popova, Popov, 2018). The structure of a web-quest includes the following parts (Soboleva, 2019): formulating the topic, aim, and name of an educational quest; conditions of fulfilling, choice situation, and the ways of its optimal solving, the form of fulfilling; planning the team's activity, assigning duties to the participants or minigroups according to the general plan. According to A. Lagunov and N. Podorojnyak, the necessary elements should include description of the criteria and parameters of assessing a web-quest; making a conclusion, presentation of the project. 
E.V. Soboleva, E.G. Galimova, Z.A. Maydangalieva, and K.K. Batchayeva prove that effective development of educational game application in order to improve the education quality is possible only if the following conditions are met (Soboleva et al., 2018):

- all the resources of educational game apps should be of interest for students;

- the process of projecting game spaces should stimulate students' cognitive processes;

- development of a game app on the basis of digital technology should cover all types of learning activity: information search, selection, systematization, critical thinking, presentation in various forms, etc.

The conclusions agree with the results presented by T.A. Shulgina, N.A. Ketova, K.A. Kholodova, and D.A. Severinov. They prove that if innovational technologies are included in educational process, the level of students' learning motivation became high (Shulgina et al., 2018). High motivation could be supported by creative projects with a well-structured route of the ways of solving the task, there should be enough texts and videos, assessing criteria should be definite, and students should be absolutely free in their solving the educational task.

At the same time, the principles of visibility, accessibility, professional orientation, relevance and novelty of information, taking into account individual characteristics, students and the level of their academic performance should be observed (Sveshnikov, 2015).

Thus, the use of web-quest technology, firstly, should rely on a complete didactic model which allows to manage students' individual learning activity through the plot and the characters, secondly, it should be rooted in the content of a definite subject (basic theories, facts, laws); thirdly, it should include the procedures of assessment and control of the competencies formed. So, it is possible to conclude that materials and methods used at the stages of designing, developing, and presenting of the quest game space are in line with the main ideas of the procedure of assessing over-professional skills (Nemtinov et al., 2020).

\subsubsection{Foreign literature review}

E. Brouwer et al. understand universal competencies as a human ability to see the connection between one's knowledge and a real state of affairs, to choose the right, suitable educational direction, and to make an algorithm of actions in conditions of uncertainty and doubt (Brouwer et al., 2020). S. Sharma defined universal competencies and skills as ones unspecific for any definite profession or sphere of activity, but important in work, education, and life in general (Sharma, 2020). E. Bordoli considers that assessing or measuring the result of forming universal competencies in practice is of greatest difficulty for digital school tutors (Bordoli, 2021).

M. Chang et al. prove that a web-quest technology is one of the forms of educational environment organization that includes the necessary resources both for learning and vocational guidance. Nowadays different kinds of research are made to describe the concept of a quest, its potential and peculiar features of inclusion in the processes of getting knowledge and career orientation (Chang et al., 2019). For example, F. Zafar, J. Wong, M. Khalil highlight the possibilities of new educational technologies for the formation of a special set of knowledge, skills and abilities that are necessary in a digital society (Zafar et al., 2018). Digital tools support working with multimedia content, they stimulate cognitive activity in searching the right decision on the spot, as well interactivity and effective feedback (Queirós, 2020). S.F. Permata et al. offer using comic strips in developing creative activity and imagination (Permata et al., 2020). The possibilities of digital technologies make it possible to realize interactions between characters, to express the plot in a new language. Stories are designed around an eight-point arc: antecedents, impulse/start, adventure goal, mystery/uncertainty, key choice, climax, turn, post-adventure events.

Z. Smyrnaiou, E. Georgakopoulou, and S. Sotiriou prove efficiency of the pedagogical technology of story-telling for showing the succession of events in an interactive form (Smyrnaiou et al., 2020). It helps to make the structure of the educational task clearer, easier to understand. Decorations stimulate cognition; allow showing scientific facts in game situations. To the authors who write the story, the following structural elements are offered: collision, intrigue, entanglement, prologue, and epilogue.

M. H. Abu Warda describes some advantages and disadvantages of computer game platforms and a specter of practical abilities for personalization of learning (Abu Warda, 2018). A variant of an educational quest is a quest-room (or quests of the type "escape the room"). This game world is fully adapted to a definite plot and each element of it suits one general story including thematic 
tasks. M. Chang et al. offer the analysis of the existing app solutions, their interface, and peculiar features of their technological support (Chang et al., 2019). Most digital tools and apps are used in the learning process just at some definite stages. They can be solving a definite system of tasks for educational and profession-oriented purposes or aiming at developing psychical processes, such as cognition, memory, attention, and imagination (Smyrnaiou et al., 2020). This state of affairs does not agree either with the specifics of using web-quests in teaching-learning (March, 1998) or with the priority trends in variability, person-oriented education, and professional training (Arif et al., 2020). These reasons reduce the didactical potential of digital apps supporting web-quest technology in conditions of forming digital educational environment. M.H. Abu Warda is one of the developers of interactive apps which can support the technology of an educational web-quest and have the potential for forming competencies most needed in modern society. The researcher states that the form and content of resources are not discussed broadly with the participants of digital educational environment in most cases (Abu Warda, 2018).

On analyzing different functions of digital services stimulating the development of students' personality and supporting teaching-learning purposes it is possible to conclude that most of them are in line with the competencies needed by professionals in the future. Still, there are some difficulties in putting in practice the potential abilities of game forms in preparing specialists who are in demand, also with the help of a web quest when it is necessary for a teacher to change the whole methodical system of education.

Projecting a system of goals should include the stage of comprehension and choice of universal competencies which can and should be formed in course of the educational process. V. Hill and K.B. Knutzen (Hill, Knutzen, 2017) consider that it is necessary to do complex work on organizing the game space of an educational web- quest, on orienting its content both to the didactic goals and the priorities of professional self-identification of a student. The projected game framework should answer the requirements of contemporary employers, be person-oriented, and take into account the needs of the participants of a web-quest (Zabolotska et al., 2021).

Thus, it is necessary to research the possibilities of a web-quest in developing personal qualities which are the most needed in modern society, such as forming universal competencies and improving the quality of higher education in general.

\section{Materials and methods}

\subsection{Theoretical and empirical methods}

For evaluating the importance of universal competencies for potential employers of higher school graduates the results of independent expert analyses and works of the NRU HSE (National Research University of Higher School of Economics) were used. The analysis of psychological and pedagogical literature of IT implementation in education helped to state the potential of the webquest technology for forming the needed universal competencies and personal qualities. At the stage of analyzing the peculiar features and elements of the story line the method of analyzing philosophical-methodological literature was used, the etymology and the structure of the word were considered. Based on the competence approach we created:

- a sequence of teaching-learning activities in working over the story line of the web-quest that suits the priorities of digital society and professional ambitions of the students as much as possible;

- principles of projecting game educational space according to the elements of the plot and the mechanisms of a web-quest;

- the procedure of evaluating the influence of work over a web-quest story line on forming the universal competencies.

System-activity approach is implemented through the help of specially made tasks, both for teaching and for control. The statements of the approach are taken into account in projecting the game environment of the educational web-quest: the game master uses tools of digital service for presenting the material; the students use functional abilities of the technology in cognitive activity; students' mutual interaction, their interaction with the characters of the web-quest and with the teacher is organized.

Empirical methods were used for experimental assessment (observation, analysis of story lines of web-quests, results of solving tasks as for a set of universal competencies formed). Game learning activity is supported by the interactive potential of Office 365. It serves as the ground for a 
sequence of events and statement of facts and actions. The programmed tools for level shifts and web-quest tasks shifts are triggers, hyperlinks, Drag-and-Drop, and macroses. The web-quest is on the cloud OneDrive, it is an information resource (https://vyatsu-my.sharepoint.com/).

To evaluate the influence of a web-quest creation on formation of the universal competencies multiple correlation analysis was used. At the stage of statistical processing, the Pearson's $\chi^{2}$ (chisquare) criterion was used.

\subsection{The base of research}

In the course of the pedagogical experiment the effect of educational web-quest technology on forming universal competencies of students as the basis for their development and professional self-actualization was assessed.

40 students of the training program 44.04.01 Pedagogical education, profile Informatization of education (master's degree level) took part in the research. Defining the type and the elements of the story line, making the plot on its basis, projecting and organizing a web-quest were made as part of teaching the discipline "Creating and using computer games in teaching". Earlier at the lessons of "IT in assessing learning and research success" students had studied ready-made webquests and technologies of their creating. Respondents' mean age was 26 years, boys and girls were equal in number.

The needed information about the students (the level of master's degree) was collected with the help of an intake test. The selection was not random. To follow the rules of a probability sampling one teacher supervised the activity of all the students. This teacher specified the system of tasks and directed the informational intercourse in the process of students' solving professional and practice-oriented tasks. Work with digital resources (in particular, with services for creating web-quests) was done in the same classrooms, using the same hardware and software. The content of the test was created by the authors in accordance with the State federal educational standard of higher education for the given field of training.

\subsection{Stages of research}

The research was conducted in three stages.

At the first stage general assessment of the level of theoretical knowledge and terms was assessed in the field. The control event included three complex tasks. Each sub-task was separately assessed. The principles of measurement are specified further in the description of experimental assessment. In control measurement it was possible to get maximum of 22 points. Then the participants were equally divided into experimental and control groups. They were divided into groups so that it was guaranteed that each group contained students with similar skills and personal qualities basic for universal competencies of a future professional in the sphere of education informational support.

At the first stage students studied the main concepts (a web-quest, game mechanics, and digital technologies in web-quests). The participants of the experiment worked with the web-quests which are already broadly used in the educational environment. They made a comparative analysis, stated didactic potential and disadvantages from the viewpoint of digitalization of education.

The second stage was devoted to specifying the principles and spheres of the tutor's supporting research activity of students in work over an account of web-quest events. A succession of teaching-learning actions in working over the story line was determined; it had to take into account the peculiar features of web-quest mechanisms and to be in line with the requirements of digital society and professional interests of master's students.

The third stage was devoted to organization of learning activity of master's students, to projecting game space according to the elements of the plot and mechanisms of a web-quest. The teacher conducted an introductory methodical lesson for all the members of the experimental group; it was devoted to explaining the grounds of the story line, its structure and types. The specific features which differentiate the story line from the plot were named, examples from different genres were given (literature, computer games, music). Special attention was paid to organization of mutual activity (team work with information sources, in Office 365 environment and in cloud service OneDrive at the stage of stating the results of the project). Groups for working over the story line 
were made and topic choice for the team web-quest was made taking into account cognitive interests, academic success, and professional orientation of the master's students.

\section{Results}

\subsection{Specification of the meaning of the main concepts}

In the paper an educational web-quest is understood as a pedagogical technology which directs students' solving the task of choosing the right variant of actions, it is done in conditions of uncertainty of the future, it includes game elements, and it is supported by digital technologies. A system of game elements is a supplement in the process of information search, making a decision, and acting according to the problem situation. The information presented in such a web-quest is used in practice; it raises the player level and, consequently, the social level of a participant.

A web-quest story line is understood as any unemotional matter-of-fact story consisting just of facts in the chronological order. Characters appear and act without being evaluated in any way by the author.

The difference between the author's understanding the concepts "story line" and "plot" consists in the fact that in a plot actions, events can be described in any order, including a reversed one, its characters can show their emotions and have their own ways, their actions get descriptions, the descriptions influence the further development of the plot.

In other words, "wrapping" in fantasy a sequence of events makes a plot out of a story line. Plot lines can cross. They form the space of a web-quest. The basis of a story is a story line. Game space of a web-quest is fully adjusted to a definite plot. At the same time each element of a webquest (including thematic tasks) should be in line with one common story, the story line (Burtseva, Burtsev, 2021).

Story line elements include 8 successive points: events before the web-quest, stimulus/start, aim/goal, enigma/uncertainty, key choice, the climax of the web-quest, a turn of events, events after the web-quest.

Web-quest game mechanics in informational discourse including triggers, hyperlinks, macros, or separate files requires the following elements: a title page, an introduction page, a page with tasks, a step-by-step instruction, and a list of references, a page of assessment, and a conclusion.

Web-quest environment includes main interactive computer-aided elements, elaborated interiors, and many latent elements. After coping with the web-quest a gamer's level is upgraded. Each space differs in decorations and characters from the previous one. For the gamers the most interesting thing is to communicate with each other, with interiors, and with the characters. The gamers find different artifacts and use them in a special way, so that they do not only get new theoretical knowledge but also open black doors and trigger mechanisms.

Surprise effect is an important part of a web-quest. Educational tasks can be of two types: search ones (to find and apply, etc.) and logical ones. Logical tasks support the plot, the story line of a web-quest, and keep its content holistic.

The main quality criteria of the web-quests are following the norms of informational safety, originality, logic nature, and connectedness; following a definite plot, creating the atmosphere of game space (Efimenko, 2019).

The work over a story line of a web-quest is grounded in search: of objects, of new knowledge, of the truth. Creating the story line of a web-quest has the following stages: correlating the educational results planned and universal competencies formed with digital functional abilities; software choice; creating the content of a web-quest (the number of statements is minimal, just enough to show logical succession); translating the story line into the game plot; conducting the web-quest; measuring the result of formation of universal competencies.

\subsection{Learning activity of creating a story line of a web-quest in teaching future professionals in the sphere of digitalization of education}

Consider a variant of practical activity on working with the story in a web-quest genre. The web-quest story line "A character has come to a job interview. An accident occurs. The participant gets into a closed space, a cabin. He/she sees a window, walls, and a door. The character spins a coin and makes a choice of the direction to go to. The coin falls down. Then a 
choice situation follows (which is actually the web-quest). The character unsets". In the experiment the story line was presented in different genres, with the help of triggers and programmed macros.

Imagine a ready story line. The idea of a web-quest: in a state corporation of "School of the future" the applicants for a vacancy in a digital information office have to undergo unusual tests. One of the applicants, a game teacher called Ilya was specially made to fall asleep. Later the ccharacter wakes up and finds himself alone in an underground dungeon. There are different signs, words, and successions of numbers on the walls around. There is also a small round window in the dungeon. Methodical recommendation: master's students can project a web-quest on the basis of their own choice of important information drawn on the walls; the specific features of the students' style in presenting and taking in information (textual, graphic, and table forms) are to be taken into account.

The future specialist had a choice: getting out through the window or through the door. To solve the dilemma he made up his mind to spin a coin which he had in his pocket: heads or tails? Heads means trying to escape through the window, tails - through the door. Methodic recommendation: a random number generator and components for processing texts can help in making the choice (for example, 1 - heads, o - tails). Still, the character dropped the coin. It disappeared. Ilya decided to add all the numbers of his date of birth. If an even number resulted, he was to open the window, if an odd number - the door. Methodic recommendation: for the choice one must use the task, all the participants should know its specifications. Coping with the task will help to activate informational intercourse within a group (the participants try to choose one of them for using his/her date of birth). If the result is that the way out is through the window, there is a message, that one can get out through the window only at the risk of one's life, One should decide if it is reasonable to run such a risk or not. Methodic recommendation: a web-quest should include tasks making the participants choose, take important decisions. It helps to form universal competencies (for example, critical thinking).

The task of level one. There are zodiac signs around the door perimeter. One should look at them and drop out the odd one. In case the answer is correct one is able to see a box with a tumbler lock. At the back side of the tile, it is written "2 raised to the $10^{\text {th }}$ power is...?" It is a task of level two. The Character dials "1024" on the timber lock. If the answer is correct the character gets the task of level three which is inside the box. There is a riddle there (for example, about the Morse alphabet). Then the character notices that the keys of the Morse alphabet are drawn on one of the walls. With the help of the hint Ilya must decipher a phrase (for example, "a Winchester"). Methodic recommendation: on this level tasks on developing communicative skills are to be used, so that information exchange could take place.

Level four. The character has a key in his hand and the door disappears. A scroll unrolls; it is a map of an underworld. One has to choose a route to find the way out. Methodic recommendation: the tasks on developing algorithm skills and programming skills should be used on the last levels of a web-quest. Most master's students have difficulties with them and show negative attitude to the necessity of following an algorithm. If such tasks are placed at level one, negative emotions can have a negative impact on the communication.

The last level. At the exit the Character sees that the door is closed, a special code is needed. The code is the number of consonants in the riddle of level one. Methodic recommendation: one of web-quest levels should include tasks on forming a multilingual capacity; students should develop this universal competence. Several variants are possible after leaving the web-space: the Character wakes up and understands it was a dream; the Character gets to a job-interview again; Ilya meets his employers and they say that he has coped successfully with the test. Methodic recommendation: the last level of a web-quest should take into account needs and cognition interests of the gamification participants in order to support a positive effect of the activity.

After passing a web-quest reflection should take place, For example, it could be a dialogue of the participants with the Character of the web-quest in a chat. It is possible to ask if they liked the role and the conditions of the adventure offered in the quest, which tasks they liked most of all, which tasks they did not like. In the chat it is possible to share one's offers, wishes, emotions, impressions, etc. It is necessary to state what was the most difficult in the quest and what new knowledge they got.

Figure 1 shows one of the variants of game space according to the projected web-quest story line. 

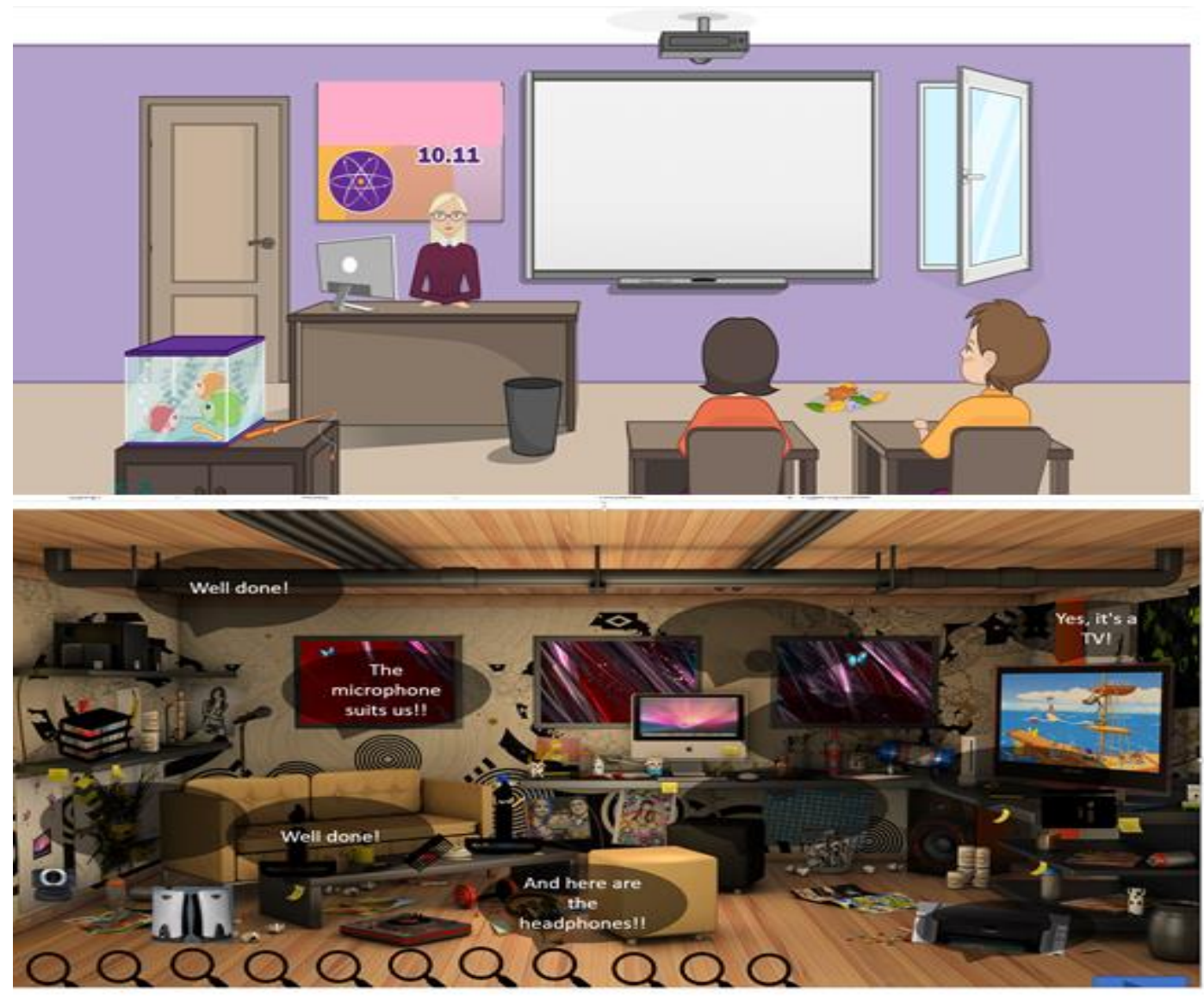

Fig. 1. An example of a web-quest story line

Then the developers of the story line created the web-quest (macros, triggers, hyperlinks) in Office 365 and placed it in the cloud service OneDrive. All the tasks and materials were put in one folder. The first task, the file "Beginning" contained the game description, its rules, and the plot. Each folder and file contained definite multiple choice tasks. Each variant of an answer had a hyperlink to a new document/resource.

\subsection{Experimental assessment}

\subsubsection{The ascertaining stage of the experiment}

At the first stage of the experiment for assessing input conditions material of a specially organized testing were used which take into account the interests of a digital society, and requirements of the standards for a specialist in the field of Informatization od Education (Prikaz Minobrnauki Rossii..., 2014).

As a part of control activities if was offered to the students to solve three complex tasks. Each sub-task was separately assessed. The principles of assessing are described by a specific example.

The criteria of assessing the efficiency of formulating the quest story line for forming universal competencies are the following: UC-1 (developing critical and system thinking) hereafter DC and ST; UC-2 (project management) - hereafter PM; UC-3 (team work) - hereafter TW. It is the most up-to-date to support the above-mentioned competencies with the mechanisms of quest technology.

Criteria: stating the important features of a project plan, using these features for choosing information from the references, data analysis, correlating the needed information with the information found before, distributing the roles among the participants, choosing the technology, presenting the result of project activity.

Sub-task 1.1 (PM). Write a curriculum and a job program taking into account the extracurricular activities of the class. For coping with the task one gets 2 points, as in the process of solving the task it is possible to use the curricular from information references in part. 
Sub-task 2.1 (PM). Project: "Schools of the world". Think over and describe the content, the project presentation. Complete performance -2 points.

Sub-task 3.1 (PM). Make five or more questions in order to update the material in the beginning of the lesson on one of the topics. Offer four variants of answer for each question. Ask an interactive question with the help of digital technologies. For coping with the task one gets 3 points.

So the maximum number of points on UC-2 is 7.

Criteria: stating the conditions of effective work of a team; searching information for team work; analyzing information, the needed results, and resources of the team; distribution of roles among the participants; choosing technologies for work; presenting the result of the team work.

Sub-task 1.2 (TW). Distribute tasks and events for which each participant. For coping with this task it is possible to get 2 points. It is possible to use the functions and roles described by the teacher before.

Sub-task 2.2 (TW). Distribute roles of the participants in the project: a creator of presentations, a thought leader, a technical expert, the main speaker, an expert from the outside (the one who asks questions). Organize the work over the project in Microsoft Teams. For full implementation it is possible to get 3 points.

Sub-task 3.2 (TW). Distribute roles in a group for an interactive questionnaire: "an excellent student”, "a bully", "a slow learner", "a whyer”, etc. For coping with the task one gets 2 points.

So the maximum number of points on UC-3 is 7.

Criteria: defining input and output conditions for the system of activity; searching information for fulfilling both each separate task and the work on the whole; critical analysis of the data acquired, the needed results and resources; effective distribution of resources; choosing technologies for implementation; correlating the result and the output conditions; presenting the results.

Sub-task 1.3 (DC and ST). Make a plan and a list of events for the next month using Google Calendar. Analyze the busiest days and distribute the load according to Sanitary Regulations and Norms. Mark the actions performed/successful with a green pencil, the actions unfinished and needing more work - with a red pencil. For coping with the sub-task one could get 3 points. Coping with that supposes checking uncertainties of the future.

Sub-task 2.3 (DC and ST). Add participants to Microsoft Teams, to place files with detailed instructions for the team and to accumulate answers to the tasks. One could get 3 points.

Sub-task 3.3 (DC and ST). Probate the interactive questionnaire in the group, compare the results of the role of a student with his/her real success in studies. For coping with the task it was possible to get 2 points.

The maximum number of points on UC-1 is 8 . All in all in check measuring it was possible to get 22 points. Then students were distributed according to the levels of competence formation on the basis of the student's total number of points got after solving all the tasks: a high level (20-22); an average level (10-19); a low level (less than 10 points).

As a result of the input checking event it was found out that student-participants of the pedagogical experiment had a similar entry level. There were 40 master's students in the total sample. Then an experimental group (20 students) and a control group (20 students) were formed. It is necessary to note that the experimental group included $50 \%$ girls and $50 \%$ boys.

\subsubsection{Forming stage of the experiment}

At the stage of the competence-forming experiment the regulations and requirements of the acting professional standard for teachers and specialists on Informatization of education in a digital school were analyzed. The regulations of the State federal educational standards mean that a student must be able to consult and use fundamental knowledge in computer science in his/her professional activity; have skills of working with information-communication technologies, communicative competence, and be able to work as a part of a team (Prikaz Minobrnauki Rossii..., 2014).

Teacher's and specialist's job in the sphere of informatization in a digital school is characterized by the following requirements: work planning, intellectual flexibility, ability to see the cognitive object in different ways, persistence, being open to new ways of solving the problems, being able to reflect, critically assess the results.

To actualize the above-mentioned requirements and to support the labour functions the following types of tasks are used: to perform activities in an algorithm sequence; to search and 
systemize information; to make a research in educational environment; to verbalize the laws found out in form of an informational model/a story line; to verbalize it down in a formal language; to work in a team (to plan, distribute the functions, to help each other, to control each other), to search different ways out of the quest and to choose the most rational one; to use informational technologies in translating the story line into the plot; to present the ready story lines and webquests in public.

At the second stage of the experiment the master's students were solving the tasks which are in line with the new trends of education and contribute to forming the universal competencies under research. For example, you get a cryptic message encoded with the help of digital technologies. If you decode it you will know the name of a means of road safety for children, it is made of light-reflecting self-sticking plastic sheet of high quality with good adhesive properties, cold and heat resistant, resistant to most dissolving agents, sun-proof, and indelible, permanent, which is due to a special polyester layer.

The master's students of the control group studied the theory of "Creating and using computer games in teaching", "IT in assessing learning and research success" and used gamification resources for educational purposes, but they did not work systematically on formulating the story line of a web-quest.

\subsection{Control stage of the experiment}

At the fixing stage of the experiment repeated measurement was done. Assessment was done according to the above-mentioned principles described in the program of the experiment. Some possible complex tasks:

1. Make a glossary on the topic. It should contain 10 or more definitions. Project a cloud of words using web-service WordArt, its content should be connected with the topic of the lesson. Place the definitions in the service, give links to the sources.

2. Organize team work on making an interactive slogan on the topic "Healthy habits" using the service Glogster. Distribute the roles among the participants. There should be such items as "Healthy food habits", "A sound mind in a sound body", "Bad habits".

3. Make an information model with the help of digital technologies. It should support making decisions on buying computers for school, it is necessary to choose one of three suppliers taking into account what set of equipment is needed, as well as the requirements, and the finance limit.

To assess the influence of working with a web-quest story line on the selected set of competencies of PM, TW, and DC and ST it was offered that increasing their level contributes to success at studies, as for all the subjects in the field of studies. ANP).

In the point-rating scale the average number of points was calculated (in Table 1, column -

Further multiple correlation analysis was used: pair correlation coefficients, matrix (D) and sub-matrix (D11) determinants, and a multiple correlation analysis coefficient $\left(\mathrm{R}_{1,2,3 \ldots \mathrm{n}}\right)$ were calculated of with MS Excel. The results are given in Table 1.

Table 1. Correlation matrix

\begin{tabular}{|c|c|c|c|c|c|c|c|}
\hline & ANP & $\mathrm{PM}$ & TW & DCandST & D & D11 & $\mathrm{R}_{1,2,3 \ldots \mathrm{n}}$ \\
\hline ANP & 1.00 & 0.72 & 0.59 & 0.79 & \multirow{4}{*}{0.10} & \multirow{4}{*}{0.36} & \multirow{4}{*}{0.86} \\
\hline $\mathrm{PM}$ & 0.72 & 1.00 & 0.36 & 0.61 & & & \\
\hline TW & 0.59 & 0.36 & 1.00 & 0.66 & & & \\
\hline DCandST & 0.79 & 0.61 & 0.66 & 1.00 & & & \\
\hline
\end{tabular}

Let's check the statistic significance of the coefficient. With the help of MS Excel functions it was calculated that $\mathrm{F}_{\mathrm{emp}}=$ 14.47. According to the tables of values of Fischer criterion $\mathrm{F}$ (for $\mathrm{p}=0.01$ ) and the degree of freedom $\mathrm{m} 1=3$ and $\mathrm{m} 2=16$ it was calculated that $\mathrm{F}_{\text {crit }}=5.29$. Thus $\mathrm{F}_{\text {emp }}=14.47>\mathrm{F}_{\text {crit }}=5.29$, and the multiple correlation analysis coefficient is statistically significant. As a result, according to Table 1, all the competencies have a positive influence on success at 
studies. System/critical thinking is the most important here, while team work skills are the least important. It was the most difficult for the students to differ a story line from a plot.

The statistical analysis of the reliability of the results of the pedagogical experiment was assessed using the Pearson's $\chi^{2}$ (chi-square) test.

Let's formulate the hypothesis:

Ho: The level of skills and habits basic for the universal competencies of master's students increased after experimental working out the story line of a web-quest; the increase is random in character.

H1: Increase of the level of skills and habits of master's students is not random.

The results of measurement before and after the experiment for master's students of both experimental and control groups are given in Table 2.

The value of test statistics before $\left(\chi 2_{\text {observ.1 }}\right)$ and after $\left(\chi 2_{\text {observ. } 2}\right)$ was calculated with the help of the on-line resource http://medstatistic.ru/calculators/calchit.html. The chosen significance level is $\alpha=0,05$. In this case $c=3$, so that the number of the degree of freedom is $v=c-1=2$.

Table 2. The results of the test

\begin{tabular}{|c|c|c|c|c|}
\hline \multirow{2}{*}{ Level } & \multicolumn{4}{|c|}{ The number of tested (undergraduates) } \\
\cline { 2 - 5 } & \multicolumn{2}{|c|}{$\begin{array}{c}\text { Experimental group } \\
\text { (20 undergraduates) }\end{array}$} & \multicolumn{2}{c|}{$\begin{array}{c}\text { Control group } \\
\text { (20 undergraduates) }\end{array}$} \\
\cline { 2 - 5 } & Before & After & Before & After \\
\hline High & 1 & 7 & 1 & 2 \\
\hline Average & 9 & 11 & 9 & 8 \\
\hline Low & 10 & 2 & 10 & 8 \\
\hline
\end{tabular}

According to the distribution tables $\chi^{2}$ for $v=2$ and $\alpha=0.05$ the statistical significance point is 5.99. So, $\chi 2_{\text {observ. } 1}<\chi 2_{\text {crit }}(0.1<5.99)$, and $\chi 2_{\text {observ. } 2}>\chi 2_{\text {crit }}(6.4>5.99)$. So that the hypothesis Ho is rejected and $\mathrm{H}_{1}$ is accepted. In other words, the work over creating the story line of a web-quest contributes to forming the needed universal competencies of master's students. The changes in the educational system are not accidental, they are quite logical.

\section{Discussion}

The choice of students was not random, as the experimental and control groups were formed so that each group contained a similar set of skills and personal qualities which are basic for universal competencies of future professionals in the sphere of Informatization of education.

The result of the input control activities were taken into account in assessing. The selection of participants of the experiment and the number of them was conditioned by the specifics of the research: studying theory in the subjects "Creating and using computer games in teaching", "IT in assessing learning and research success", using gamification resources in education is included in a limited number of curricula. During the experiment one and the same teacher guided solving profession-oriented tasks in practice with the use of digital technologies, the same equipment and the same class-rooms were used. The main didactic principles and the functional abilities of tools for creating web-quests were taken into account.

In the analysis of the results, according to Table 1 , it is possible to state that success at studies in general directly depends on all the competencies. System/critical thinking is most important here, while team work skills are the least important. The experiment showed that it is the most difficult for the students to differ the story line from the plot.

Development of the content into the plot and making a web-quest by means of digital technology was not very resource-consuming. The content allowed transforming the web-quest space, and the hardware tools were known before.

In most cases the basis of the web-quest was overloaded with characters and events. Besides, many students tried to evaluate the characters' deeds, ascribed to them features which could influence their deeds. The other issue is connected with making an outline of the events in a chronological order, and in stating logical links between the facts. A web-quest should include elements and mechanisms of game input and events which require making a choice. At the same 
time in the story line of a web-quest they should follow each other in a strict sequence. Sometimes students tried to show the event so that to make the web-quest more captivating, as they see it. For example, the gamer could find three data transmission cables at once. Or the character had to choose either probability or alphabetic approach to assessing information. A web-quest story-line can contain only the following variant: the character chooses the translation rule, the character chooses address wire/databus line.

The research results supplement the ideas of Z. Smyrnaiou, E. Georgakopoulou, S. Sotiriou (Smyrnaiou et al., 2020) on structural elements of the story line as they are applied to the game space of a web-quest. Methodical difficulties at adjusting the plot to the topic, at making a system of tasks for each level of a web-quest, at adjusting the labour market requirements to the abilities of the web-quest participants agree of conclusions made by E.V. Soboleva (Soboleva, 2019).

Thus, creating the story line of a web-quest allowed creating special conditions for development of creative and cognitive activity, increasing information intercourse, supporting management of one's own and other people's deeds, using theoretical knowledge in practice, increasing the quality of education on the whole. The universal competencies needed in a digital society were effectively formed.

\section{Conclusion}

The research offers a solution of the problem which consists in the necessity to resolve the conflict between the society's requirements to the quality of master's students' abilities and the faults of the system of a web-quest technology used in the process of educating the students who are to answer the above-mentioned requirements.

One of the research results is a definition of the story line as a structure-forming and meaningful element of a quest (together with the plot, characters). An important theoretical result is specifying the concept "a web-quest content" as an unemotional background for a story, facts enumeration in a chronological order. The paper describes the stages of creating the story line: defining a set of the universal competencies formed, choosing a tool for creating a web-quest, writing the story line of a web-quest, translating the story line into a game plot, performing a webquest, assessing the formation of universal competencies as a result.

Many master's students use all the elements of the content in their projects: the events proceeding to the web-quest, the starting event (the trigger), the goal-event, enigma-events and miracle-events, events for choice, events as consequences, events as turning points, the position of the character after leaving the web-quest. Besides, they describe the plot-lines, relations between the characters, i. e. the game mechanism. The paper describes the procedure and the principles of forming the universal competencies. The efficiency of the offers is proved by the pedagogical experiment. The issues of working with the story line of a web-quest are specially mentioned: stating just the facts in their chronological order, avoiding the author's evaluations, affirming the aim of the web-quest the most important thing for all the deeds and all the characters of the web-quest, minimizing the number of aims of the web-quest (not more than two). To solve the above-mentioned tasks at the first stages of creating the story line it is recommended to follow the recommendations:

1. Put down the story line in three-four sentences, point out the characters and locations. Draw a line and place the key moments of the story on it. Number the events and decide if coping with all the tasks leads the characters to achieving the aim of the web-quest.

2. Practice the skill at stories which are simple and well-known in detail, such as "The one from the future", "Transformers", etc.

3. When the story line is ready to your mind, ask someone to read it (someone who knows the game mechanism of a web-quest), ask the person to name all the structural elements in a logical order.

The research results can be used not only in forming students' universal competencies and in gamification of education, but also for the sake of increasing the quality of higher education in general.

\section{References}

Abu Warda, 2018 - Abu Warda, M.H. (2018). The Impact of Collaborative Learning on Web Quest Strategy Used in Learning Educational Psychology. International Journal of Web-Based Learning and Teaching Technologies. 13(4): 77-90 
Arif et al., 2019 - Arif, F.K.M., Zubir, N.Z., Mohamad, M., Yunus, M.M. (2019). Benefits and challenges of using game-based formative assessment among undergraduate students. Humanities and Social Sciences Reviews. 7(4): 203-213. DOI: https://doi.org/10.18510/hssr.2019.7426

Astashova et al., 2018 - Astashova, N.A., Bondyreva, S.K., Smantser, A.P. (2028). Razvitie aksiosfery budushhego pedagoga $\mathrm{v}$ dialogovom prostranstve sovremennogo obrazovanija [Development of the axiosphere of the future teacher in the dialogue space of modern education]. Obrazovanie i Nauka. 20(7): 32-67. [in Russian]

Belkina, Makeeva, 2018 - Belkina, V.V., Makeeva, T.V. (2018). Koncept universal'nyh kompetencij vysshego obrazovanija [Concept of higher education universal competencies]. Yaroslavskij pedagogicheskij vestnik. (5): 117-126. [in Russian]

Bordoli, 2021 - Bordoli, E. (2021). Curricular design for competencies in basic education in uruguay: Positions and current debates (2008-2019). Comparative Education. 57(1): 67-82.

Brouwer et al., 2020 - Brouwer, E., Driessen, E., Mamat, N.H., Nadarajah, V.D., Somodi, K., Frambach, J. (2020). Educating universal professionals or global physicians? A multicentre study of international medical programmes design. Medical Teacher. 42(2): 221-227.

Burtseva, Burtsev, 2021 - Burtseva, M.A., Burtsev, A.A. (2021). Osobennosti fabul'noj organizacii goticheskogo teksta (na materiale rasskaza Je.G. Sujejna "Indijskij abazhur") [The plot structure in the Gothic text (the case of E.G. Swain's "The Indian lampshade")]. Filologicheskie Nauki. Nauchnye Doklady Vysshej Shkoly. 1: 88-95. [in Russian]

Chang et al., 2019 - Chang, M., Chen, C.T., Wu, K.H., Yu, P.S. (2019). Conversation Quest in MEGA World (Multiplayer Educational Game for All). Foundations and Trends in Smart Learning. 77-82. DOI: https://doi.org/10.1007/978-981-13-6908-7_10 (date of access: 1.05.21)

Efimenko, 2019 - Efimenko, A.E. (2019). Ot sujet k sjuzhetu i dalee k syuzhet [From sujet to plot and on to syuzhet]. Shagi-Steps. 5(2): 10-35. [in Russian]

Frumin et al., 2018 - Frumin, I.D., Dobryakova, M.S., Barannikov, K.A., Remorenko, I.D. (2018). Universal'nye kompetentnosti i novaja gramotnost': chemu uchit' segodnja dlja uspeha zavtra. Predvaritel'nye vyvody mezhdunarodnogo doklada o tendencijah transformacii shkol'nogo obrazovanija [Universal competencies and new literacy: what to teach today for success tomorrow. Preliminary conclusions of the international report on trends in the transformation of school education]. Nacional'nyj issledovatel'skij universitet «Vysshaja shkola ekonomiki», Institut obrazovanija. 28. [Electronic resource]. URL: http://vcht.center/wp-content/uploads/2019/o6/ VSHE-pro-novye-kompet-i-gramotnosti.pdf [in Russian]

Grinshkun et al., 2019 - Grinshkun, V., Bidaibekov, E., Koneva, S., Baidrakhmanova, G. (2019). An essential change to the training of computer science teachers: The need to learn Graphics. European Journal of Contemporary Education. 8(1): 25-42.

Hill, Knutzen, 2017 - Hill, V., Knutzen, K.B. (2017). Virtual world global collaboration: an educational quest. Information and Learning Science. 118-9/10: 547-565. DOI: https://doi.org/ 10.1108/ILS-02-2017-0010 (date of access: 01.04.21).

Isupova, Suvorova, 2018 - Isupova, N.I., Suvorova, T.N. (2018). Sozdanie sistemy uchebnyh situacij s ispol"zovaniem tekstovogo labirinta [Creating a system of learning situations using text labyrinth]. Informatika i obrazovanie. 4: 37-41. [in Russian]

Koreshnikova et al., 2020 - Koreshnikova, Y.N., Frumin, I.D., Pashchenko, T.V. (2020). Bar'ery dlja sozdanija pedagogicheskih uslovij razvitija kriticheskogo myshlenija v rossijskih vuzah [Barriers to creating pedagogical conditions for the development of critical thinking in russian universities]. Pedagogika. 84 (9): 45-54. [in Russian]

Krupkin, Sinyakova, 2020 - Krupkin, A., Sinyakova, M. (2020). Identification of relevant interactive teaching methods for the development of universal competencies of future engineers. In book: Integrating Engineering Education and Humanities for Global Intercultural Perspectives, Proceedings of the Conference "Integrating Engineering Education and Humanities for Global Intercultural Perspectives”, 25-27 March 2020, St. Petersburg, Russia (pp. 652-658).

Kuzminov et al., 2019 - Kuzminov, Ya., Sorokin, P., Froumin, I. (2019). Generic and Specific Skills as Components of Human Capital: New Challenges for Education Theory and Practice. Foresight and STI Governance. 13(2): 19-41.

Lagunov, Podorojnyak, 2017 - Lagunov, A., Podorojnyak, N. (2017). Quest like form of MOOC organizing. 16th International Conference on Information Technology Based Higher 
Education and Training (ITHET). DOI: https://doi.org/10.1109/ITHET.2017.8067803 (date of access: 1.07.19).

March, 1998 - March, T. (1998). Web-Quests for Learning. [Electronic resource]. URL: http://www.ozline.com/webquests/intro.html (date of access: 01.07.19)

Nemtinov et al., 2020 - Nemtinov, V.A., Borisenko, A.B., Morozov, V.V., Nemtinova, Y.V. (2021). Povyshenie urovnja professional'nyh kompetencij $\mathrm{s}$ ispol'zovaniem virtual'noj obrazovatel'noj sredy [Increasing the level of professional competence using a virtual educational environment]. Vysshee obrazovanie $v$ Rossii. (3): 104-113. [in Russian]

Permata et al., 2020 - Permata Sari, F., Nikmah, S., Kuswanto, H., Wardani, R. (2020). Development of physics comic based on local wisdom: Hopscotch (engklek) game android-assisted to improve mathematical representation ability and creative thinking of high school students. Revista Mexicana De Fisica E. 17(2): 255-262.

Popova, Popov, 2018 - Popova, M.N., Popov, I.P. (2018). Ispol'zovanie kvest-tekhnologij pri provedenii vneurochnoj deyatel'nosti po fizike [The use of quest technologies when conducting extracurricular activities in physics]. Perspektivy nauki i obrazovanija. 33-3. [Electronic resource]. URL: https://elibrary.ru/item.asp?id=35204111 (date of access: 01.07.19). [in Russian].

Prikaz Minobrnauki Rossii..., 2014 - Prikaz Minobrnauki Rossii ot 21.11.2014 N 1505 "Ob utverzhdenii federal'nogo gosudarstvennogo obrazovatel'nogo standarta vysshego obrazovanija po napravleniju podgotovki 44.04.01 Pedagogicheskoe obrazovanie (uroven' magistratury) [Order of the Ministry of Education and Science of the Russian Federation of 21.11.2014 N 1505 " On approval of the Federal State Educational Standard of Higher Education in the field of training 44.04.01 Teacher Education (Master's Degree level)]. [Electronic resource]. URL: http://fgosvo.ru/uploadfiles/fgosvom/440401.pdf

Queirós, 2020 - Queirós, R. (2019). PROud-A gamification framework based on programming exercises usage data. Information (Switzerland). 10(2): 54 .

Serditova, Belotserkovsky, 2020 - Serditova, N.E., Belotserkovsky, A.V. (2020). Obrazovanie, kachestvo i cifrovaja transformacija [Education, quality and the digital transformation]. Vysshee Obrazovanie v Rossii. 29(4): 9-15. [in Russian]

Sharma, 2020 - Sharma, S. (2020). A poststructural analysis of study abroad as teacher preparation pedagogy: Thinking through theory for generative practice. Theory into Practice. 59(3): 310-320.

Shulgina et al., 2018 - Shulgina, T.A., Ketova, N.A., Kholodova, K.A., Severinov, D.A. (2018). O motivacii studentov $\mathrm{k}$ uchastiyu $\mathrm{v}$ organizacii meropriyatij professional'noj napravlennosti [Motivating students to participate in professionally oriented events management]. Obrazovanie i nauka. 20(1): 96-115. DOI: https://doi.org/10.17853/1994-5639-2018-1-96-115 (date of access: 01.07.19). [in Russian]

Smyrnaiou et al., 2020 - Smyrnaiou, Z., Georgakopoulou, E., Sotiriou, S. (2020). Promoting a mixed-design model of scientific creativity through digital storytelling - the CCQ model for creativity. International Journal of STEM Education. 7(1).

Soboleva, 2019 - Soboleva, E.V. (2019). Quest in a Digital School: The Potential and Peculiarities of Mobile Technology Implementation. European Journal of Contemporary Education. 8(3): 613-626.

Soboleva et al., 2018 - Soboleva, E.V., Galimova, E.G., Maydangalieva, Z.A., Batchayeva, K.K. (2018). Didactic value of gamification tools for teaching modeling as a method of learning and cognitive activity at school. Eurasia Journal of Mathematics, Science and Technology Education. 14(6): 2427-2444. [Electronic resource]. URL: https://10.29333/ejmste/89843 (date of access: 1.04.21).

Sveshnikov, 2015 - Sveshnikov, A.V. (2015). Tvorcheskij process kak jesteticheskaja kategorija [Creative process as an aesthetic entity]. Vestnik VGIK. (3): 84-97. [in Russian]

Zabolotska et al., 2021 - Zabolotska, O., Zhyliak, N., Hevchuk, N., Petrenko, N., Alieko, O. (2021). Digital competencies of teachers in the transformation of the educational environment. Journal of Optimization in Industrial Engineering. 14(1): 43-50.

Zafar et al., 2018 - Zafar, F., Wong, J., Khalil, M. (2018). Gamifying higher education: enhancing learning with mobile game app. Proceedings of the Fifth Annual ACM Conference on Learning at Scale. 1-2. [Electronic resource]. URL: http://dl.acm.org/citation.cfm?doid=3231644. 3231686 (date of access: 27.05.2019). 